\title{
Methodological aspects of the analysis of multinational enterprises
}

\section{OLEKSANDR ROGACH}

\begin{abstract}
The article analyzes the history of the terminology of the firms engaged in foreign direct investment (FDI) and international production, its evolution in the scientific literature on international business, as well as in the official publications of the UN and other international organizations. There are examined the historical circumstances and reasons for the introduction of the "transnational corporations" (TNCs) name by a special UN commission in 1974. The classification of international firms in domestic economic literature is characterized by the methodological basis of the criterion of monoethnic or multiethnic ownership. Argumentation of the main trends of international business theory in the terminology of companies engaged in foreign production and investment activities is characterized, as well as the dominance of the definition of multinational enterprises (MNEs) in the literature on these issues. The article examines the change of traditional ideas about an international company during the past decades, caused by the inclusion in the internationalization process of state-owned companies, small and medium-sized companies, including from countries with emerging markets, the transition of multinational enterprises from ethnocentric to regiocentric and geocentric orientation, the appearance of "born as global" firms. The modern profile of these enterprises and the trends in the international movement of their capital are characterized, in particular, the mechanisms of "diffusion and blurring of nationality" of the share capital of modern international companies are revealed as a result of the property restructurisation and consolidation of capital, sale of shares on international stock exchanges, cross-border mergers and acquisitions (MAs). The role of tax inversions of corporations, transit hubs of the movement of foreign direct investment, and income and investments accumulation centers in further interweaving of capital and masking of national property of the MNE is highlighted. The article argues that the key feature of modern FDI and international manufacturing firms is multinationality. This confirms not only the blurring of the national character of such firms' ownership, but also the multinational character of their strategic management, the network architecture of knowledge creation and the fragmented process of added value creation. The article proves the secondary nature of quantitative criteria in MNE determination and the multinationality priority as an essential feature of such institution. Based on the characteristics of many theoretical and practical aspects of modern foreign production and investment activities of firms, the article substantiates the feasibility of 'multinational enterprises' term usage for such institutions with the aim of further integrating of Ukrainian economic science into the world's school of international business research.
\end{abstract}

KEY WORDS: foreign direct investments, international production, international firms, capital internationalization, transnational corporations, multinational enterprises, theory of international business.

\footnotetext{
* This article was translated from its original in Ukrainian.

${ }^{1}$ Rogach Oleksandr Ihorovych - Doctor of Economics, Professor, Head of the Department of International Finance at the Institute of International Relations of Taras Shevchenko National University of Kyiv. Honoured Economist of Ukraine. Sphere of scientific interest: international flows of capital, internationalization of capital and production, multinational enterprises, international finance. E-mail: mf.roi.@clouds.iir.edu.ua
}

IEP, № 31, (2019) pp. 7-42

(C) Oleksandr Rogach, 2019 «All rights reserved»

ISSN 1811-9832/2019/№ 2 (31) 


\section{Introduction}

Several terms to refer the companies engaged in foreign direct investment (FDI) and international production can be found in domestic literature. But the term of a transnational corporation (TNC) still prevails. The author used the TNC term for many years in his monographs and textbooks on this subject. But sometimes it makes one wonder, why do we call firms that have embarked the path of internationalization that way, especially that most of scientists in the USA, Canada or Europe call them "multinational enterprises (firms)". Change of the basic terminology is usually a complex and slow process. It is necessary to overcome the inertia of traditionality and make sure that innovation is correct. The substantive examination of all the streams of the international business theory, in particular, their interpretation of definition and names of firms engaged in international production and investment activities is so important. On the basis of such long-term study, a decision to abandon the traditional domestic term and adopt the universally recognized term of "multinational enterprise" (MNE) has appeared, and it was done in the latest textbooks "Theory of International Business" (2018) ${ }^{2}$ and "Multinational enterprises" (2019) ${ }^{3}$. This article provides the reasons that finally convinced me to make that choice.

\section{Historical circumstances of terminology formation}

In the early 1970s, an extremely significant event took place in the world economy - the volume of international production (i.e. the gross production of MNE foreign branches) exceeded the volume of world exports of countries with a market economy - respectively USD 330 against USD 310 billion for the first time in the history of capitalism ${ }^{4}$. We can consider this particular line as the beginning of a new, modern stage in the internationalization of capital and production.

In the first half of the 1970s, the first wave of fundamental research of firms that carried out FDI and international production appeared in world literature. R. Barnet and R. Muller ${ }^{5}$, P. Buckley and M. Casson ${ }^{6}$,

\footnotetext{
${ }^{2}$ Rogach O. Theory of International Business (ukr. Teoriyi mizhnarodnogo biznesu) / O. Rogach. - K.: VPT «Kiyivskiy universitet», 2018. - 687 p. [In Ukrainian].

3 Rogach O. Multinational Enterprises (ukr. Bagatonatsionalni pidpriemstva). Pidruchnik. / Oleksandr Rogach. - Kyiv: VPT «Kiyivskiy universitet», 2019. - 387 p. [In Ukrainian].

${ }^{4}$ UN. Multinational Corporations and World Development /UN. - New York, 1973. - pp. 8-14.

${ }^{5}$ Barnet R. Global Reach: The Rise of the Multinational Corporation / R. Barnet, R. Muller. - New York, Touchstone, 1974. - $508 \mathrm{p}$.

${ }^{6}$ Buckley P. The Future of the Multinational Enterprise / P. Buckley, M. Casson. — New York: The McMillan Company, 1976. -116 p.
} 
L. Turner ${ }^{7},{ }^{8}$, J. Stopford and L. Wells ${ }^{9}$, R. Gilpin ${ }^{10}$, J. Dunning ${ }^{11}$, F. Knickerbocker ${ }^{12}$, and pioneer articles of S. Hymer ${ }^{13},{ }^{14}, \mathrm{R}$. Vernon ${ }^{15}$ monographs received a wide scientific resonance. $\mathrm{M}$. Wilkins, one of the world's largest authorities in the field of the international business history, has published two best-selling monographs during these years, they analyze the history of capital export and the growth of international firms, from colonial times to the 70 s of $\mathrm{XX}$ centuries ${ }^{16},{ }^{17}$. There is used the term Multinational corporation (enterprise, firm, company) in all of these publications, which was translated in the same way. New conceptual approaches to the study of the internationalization of firms and foreign direct investment were launched in these studies, which, as will be further shown by us in this article, subsequently constituted the architecture of the international business science.

In 1973, a special UN experts group prepared a fundamental review of the multinational enterprises activities, for the first it generalized quantitative assessments of their activities and their influence on the global economy development. This study was called Multinational Corporations and World Development and was distributed as an official UN document. Subsequently, this review was published by Praeger Publishers printing house as a separate book and received worldwide attention $^{18}$. In fact, the research of UN experts was the first fundamental empirical study of multinational firms in the world and caused a huge wave of further publications on this subject. During the next ten years, this publication was the most quoted by researchers in the production and capital internationalization sphere.

By the beginning of the 1970s, almost all courses of the international business theory used Multinational Corporations term or very similar

\footnotetext{
${ }^{7}$ Turner L. Multinational Companies and the Third World / L. Turner. - New York, 1973.

${ }^{8}$ Turner L. Invisible empires: Multinational companies and the modern world / L. Turner, Houghton Mifflin Harcourt, 1970.

${ }^{9}$ Stopford J. Managing the multinational enterprise: Organization of the firm and ownership of the subsidiary / J. Stopford, L. Wells Jr., - NY: Basic Books, 1972.

${ }_{10}$ Gilpin R. US Power and the Multinational Corporations: The Political Economy of Foreign Direct Investment / R. Gilpin, W. Gilpin. — New York: Basic Books, 1975. — 246 p.

${ }^{11}$ Dunning J. H. (Ed.). International investment: selected readings / Dunning J. H. (Ed.). - Penguin, 1972.

12 Knickerbocker F. Oligopolistic Reaction and Multinational Enterprise / F. T. Knickerbocker. - Cambridge, MA: Harvard Business School Division of Research, 1974.

${ }_{13}$ Hymer S. The efficiency (contradictions) of multinational corporations / S. Hymer // The American Economic Review, 60(2), 1970. - pp. 441-448.

${ }_{14}^{14}$ Hymer S. The internationalization of capital / S. Hymer // Journal of economic issues, 6(1), 1972. — pp. 91-111.

15 Vernon R. Competition policy toward multinational corporations / R. Vernon // The American economic review, 64(2). - pp. 276-282.

${ }^{16}$ Wilkins M. The emergence of multinational enterprise: American business abroad from the colonial era to 1914 / M. Wilkins. - Cambridge, Mass: Harvard University Press, 1970.

${ }_{17}$ Wilkins M. The maturing of multinational enterprise: American business abroad from 1914 to 1970 / M. Wilkins. - Cambridge, Mass: Harvard University Press, 1974. $232 \mathrm{p}$.

${ }^{18}$ UN. Multinational Corporations and World Development / UN. - New York: Praeger Publishers, 1974. _
} 
names (multinational firms, companies, enterprises). For the first time, the early theories of FDI and international firms grounded foreign direct investments as a special form of capital export, showed the patterns of firm foreign production operations. S. Hymer was the first scientist who paid attention on the need to distinguish the foreign direct investments from portfolio investments, based on the criteria for direct control over foreign assets. He believed that firms that have subsidiaries abroad should be called as multinational companies ${ }^{19}$. C. Kindlberger, the supervisor of Hymer's PhD thesis, who in his theory of "monopolistic advantages" developed and strengthened the arguments of S. Hymer's theory of market power, used the similar terminology ${ }^{20}$.

Another early theory of the internationalization of production and capital export was substantiated by $\mathrm{R}$. Vernon. He was engaged to one of the largest and longest-running projects in the academic history of firms' international operations study (the Harvard University Project for the Study of Multinational Firms Activities, 1963-1986), who paid particular attention on the terminology of such institutions. Although the researcher called the most internationalized group of international firms as global companies, he finally appointed the name of multinational enterprises to firms that carry out foreign direct investments ${ }^{21}$. Subsequently, leading authorities in the field of international business, in particular A. Ruhman, M. Casson, P. Buckley, J. Dunning, emphasized a more precise substantive basis of the name of multinational enterprises in comparison with other definitions of these companies ${ }^{22}$.

By the middle of $1970 \mathrm{~s}$, the Transnational Corporations name was rarely used in the scientific literature. Approximately all publications on foreign direct investments and international production problematics used the multinational corporations name.

The activities of multinational firms at this time was at the center of public attention and political discussion. This was caused not only by the high rate of internationalization of US, European, Japanese firms, but also by frequent cases of corruption, economic abuse and interference by these companies in the political life of the countries. For example, the intervention of the American multinational company ITT in the political life of Chile during the overthrow of the power of President Allende received the widespread publicity. As it turned out

\footnotetext{
${ }^{19}$ Hymer S. The International Operations of National Firms: A Study of Direct Investment / S. Hymer. — MIT Press, 1976. - $183 \mathrm{p}$.

${ }^{20}$ Kindleberger C. American Business Abroad. Six Lectures on Direct Investment. New Haven and London / Ch. Kindleberger. - Yale University Press, 1969. - 210 p.

21 Vernon R. International Investment and International Trade in Product Cycle / Vernon R. // Quarterly Journal of Economics, 1966, Vol. 80 - № 2, — pp. 190-207.

${ }_{22}$ Buckley P., Casson M. The Future of Multinational Enterprise / P. Buckley, Casson M. - London: Macmillan, 1976. - pp. 32-66.
} 
during the investigation of the US Senate commission, ITT tried to prevent the government of President Allende from coming to power, and when it was failed, financed his overthrow in order to return nationalized assets in the amount of USD 200 million $^{23}$.

As R. Vernon wrote at that time, "the most threatening aspect of the activity of multinational enterprises ... is connected with the potential role of these enterprises as agents of foreign governments" ${ }^{24}$. In addition, the young independent states of Asia, Africa, and Latin America sharply criticized the control of multinational firms on their natural resources and proclaimed their sovereign right to nationalize the assets of former colonial firms in resource-based industries.

Against the backdrop of these events, by the decision of the UN in 1972, a working group on issues of multinational firms, which included representatives of scientific communities, the public and government institutions from many countries (The Group of Prominent Persons) was formed. Its goal was to collect information on $\mathrm{MNE}$ and to prepare recommendations for UN institutions. One of the first issues of the work of experts group from multinational corporations was the definition of terminology of these firms. This issue was discussed for a long time, but after all, political considerations played a crucial role.

A group of Latin American member countries of the Andean Pact grouping tried to establish control over the activities of foreign companies since 1970. The documents of the Cartagena Agreement Commission and the Andean Code of Foreign Investment Regulation (revision 1970) first introduced the classification of international firms into transnational and multinational. The Andean Code provided for the possibility of imposition of sanctions against foreign affiliates, restriction of the capital repatriation, reinvestment of profits, regulation of the use of external credits and transfer of technology from mother firms ${ }^{25}$. Acute disputes arose between the governments of some of these countries and international firms at this time. As a result, for example, in the early 1970s, General Motors, Ford Motors, Exxon, Kodak and other MNEs refused to carry out 84 investment projects in the countries of this group ${ }^{26}$. Since the countries of the Andean group created their common, so-called multinational firms according to the program of integration activities of this organization, they proposed to name the

\footnotetext{
${ }^{23}$ Ingram G. Expropriation of U.S. Property in South America / G.M. Ingram. — New York: L., 1974. — pp. 303-304.

${ }^{24}$ Vernon R. Multinational Enterprise and National Security / R.Vernon // Adelphy Papers, No. 74 - London: The Institute of Strategic Studies, 1971. - p. 17.

${ }_{25}$ Lukianenko D., Poruchnik A. Universalizatsiya funktsiy mezhdunarodnyih institutov regulirovaniya proizvodstvenno-obmennoy deyatelnosti. In: Global Economic Development: Tendencies, Asymmetries, Regulation (rus. Globalnoe ekonomicheskoe razvitie: tendentsii, asimmetrii, regulirovanie) / D. Lukianenko, A. Poruchnik. K.: KNEU, 2013. - pp. 395-408. [In Russian].

${ }^{26}$ Turner L. Politics and the Multi-national Company / L. Turner - L., 1969. — C. 14.
} 
companies of industrialized countries with foreign branches as transnational corporations $(\mathrm{TNCs})^{27}$. So, the main idea of this initiative was distinction between firms in industrialized countries and jointing of firms in developing countries. Discussions in the UN Security Council on ITT policies in Chile added an additional political argument for the position of the Andean Pact group ${ }^{28}$.

The proposal of the Andean Pact group was supported by the "77 Group of 77 (G77)" (an intergovernmental organization of developing countries that operated within the UN). The Soviet Union also actively endorsed the initiative of the Latin American countries. Representatives of the USSR in the UN expert group emphasized on the need to distinguish difference between "imperialist" and "non-imperialist" international companies. According to the archival minutes of the UN Commission of Experts on Multinational Corporations meetings, representatives of the academic community from industrialized countries expressed criticism and doubts about the appropriateness of the TNCs name, since all business, scientific and statistical publications used the term of multinational corporations at that time ${ }^{29}$. After long discussions, the above-mentioned expert working group (which was dominated by representatives of developing countries and former socialist countries) agreed with the initiative of the Latin American countries. Since that time, the term of Transnational Corporations has become principal in official documents and publications of the United Nations. In 1974, the UN Commission on TNCs was established, and subsequently the UN Center on $\mathrm{TNCs}^{30}$.

The opinion of experts of industrialized countries on changing the name of international firms was clearly certified in the name of the "Committee on International Investments and Multinational Enterprises" created within the Organization for Economic Cooperation and Development (OECD) in 1975. The OECD's first basic document on the regulation of foreign investment with the name of "OECD Declaration on International Investment and Multinational Enterprises" 31 , which once again clearly indicates the official name of such firms, was published in 1976. Hereinafter, all documents of the OECD began to use only this term ${ }^{32}$. The World Trade Organization

27 Rogach O. Transnational Corporations (ukr. Transnatsionalni korporatsiyi) / O. Rogach. - K.: VPT «Kiyivskiy universitet», 2008. - p. 18 [In Ukrainian].

${ }_{28}$ UN. The Impact of Multinational Corporations on Development and on International Relations / UN. New York, 1974. - pp. 57-58.

29 UN. Summary of the Hearings before the Group of Eminent Persons to Study the Impact of Multinational Corporations on Development and on International Relations / UN. - New York, 1974.

${ }^{30}$ ECOSOC. Res. 1913 (LVII) / ECOSOC.

31 OECD. The OECD Declaration and Decisions on International Investment and Multinational Enterprises: Basic Texts. https://www.oecd.org/daf/inv/investment-policy/ConsolidatedDeclarationTexts.pdf

32 OECD. OECD Guidelines for Multinational Enterprises. 2011 Edition. https://www.oecd.org/daf/ $\mathrm{inv} / \mathrm{mne} / 48004323$.pdf 
(WTO), after its creation, in one of the first reports "Trade and Foreign Direct Investments" (1996) also introduced the term multinational corporations (MNC) ${ }^{33}$. Both in the WTO documents and in the speeches of the leaders of this organization of companies engaged in international production are designated as multinational enterprises ${ }^{34}$. Pascal Lamy, Director General of WTO in his report on February 9, 2011 emphasized that "multinational corporations play a major role in international trade"35. In 1972 the International Labor Organization (ILO) created the "Group of Experts on the Relationship Between Multinational Corporations and Social Policy", and in 1977 ILO adopted the "Tripartite Declaration of Principles Relating to Multinational Corporations and Social Policy"36. This name of international firms was used in the future in the documents of this organization. A special group of experts (Multinational Enterprise Group) has also been formed in the European Union, which is developing FDI methodology in Eurostat and collecting data on multinational enterprises in these countries ${ }^{37}$.

None of the economic schools of research on the internationalization of firms that began to develop rapidly since these times also changed the terminological approaches to the name of international companies. Most publications and research on this issue continued to use the phrase multinational firms (companies, corporations). There can be found the name of Global Companies in some scientific works, although this term is mainly used in publicistic literature and journalistic articles. It should also be noted that the names of firms that implemented by FDI, such as supranational, supernational, and international corporations, have almost not assimilated in the scientific literature. Different national economic schools have their own traditions regarding the names of such firms. For example, the term of a multinational corporation (firm, enterprise) dominates in the economic literature of the USA, Great Britain and Japan. There can be found a greater variety of names of such companies, although the multinational enterprises name also prevails in the publications of scientists from Western Europe.

33 WTO. Trade and foreign direct investment. Geneva: WTO, 1996. https://www.wto.org/english/ news e/pres96 e/pr057_e.htm

${ }^{34}$ WTO. Technological Innovation, Supply Chain Trade, and Workers in a Globalized World. WTO, Geneva, 2019, _ pp.76, 156, 157. https://www.wto.org/english/res_e/booksp_e/gvc_dev_report 2019 e.pdf

35 Lamy P. Sports equipment typifies new global production pattern. $\overline{\mathrm{h} t \mathrm{t} s}: / / \mathrm{w} w \mathrm{w} . \mathrm{wto} . \mathrm{org} / \mathrm{english} /$ news_e/sppl_e/sppl185_e.htm

${ }^{36}$ ILO. Tripartite Declaration of Principles concerning Multinational Enterprises and Social Policy. International Labour Office, Geneva, Murch 2017 - p.3. https://www.ilo.org/wcmsp5/groups/public/---ed emp/--emp ent/---multi/documents/publication/wcms_094386.pdf

${ }^{37}$ EU. Multinational Enterprise Groups and Their Structure. EUROSTAT. https://ec.europa.eu/eurostat/web/ experimental-statistics/multinational-enterprise-groups 
In the early 1970s, the first monographs and articles on the problems of multinational enterprises also appeared in the economic literature of the former USSR. They used two related terms - "international corporations" and "multinational corporations". These, in particular, were the works of I.D. Ivanov ${ }^{38}$, T.Ya. Bielous ${ }^{39}$, N.A. Karahodina ${ }^{40}$, A.Z. Astapovuch ${ }^{41}$, H.N.Klymko ${ }^{42}$ and others ${ }^{43}$.

In the second half of the 1970s, the first $\mathrm{PhD}$ theses on this issue were defended for the Doctor of Economics degree, (H.H. Chibrykov ${ }^{44}$, T.Ya.Bielous ${ }^{45}$ ), who also theoretically and methodologically prove the international (multinational) corporations', firms', monopolies' name. But after the adoption by the UN commission of the TNCs name in the scientific publications of scientists of the former USSR, a transition to a new name of international enterprises took place. I.D. Ivanov, the leading Soviet researcher of international firms wrote on this occasion that "the question of a scientifically grounded definition of a transnational corporation, raised in practical terms, has also turned into a field of intense political and even ideological struggle ... TNCs artificially include the opposite or state-owned companies of developing countries, as well as countries of socialism ..." ${ }^{46}$. That is why it was suggested to mean TNCs as "private companies powerful enough to produce political and other influence on the countries where they operate" 47 . According to I.D. Ivanov, "These are 400 billionaire companies. And first of all, 250 giant corporations with branches in more than 20 countries of the world" 48 .

\footnotetext{
${ }^{38}$ Ivanov I. D. Multinational Corporations in Global Economy (rus. Mezhdunarodnyie korporatsii v mirovoy ekonomike) / I. D. Ivanov. — M.: Myisl, 1976. — 215 p. [In Russian].

${ }^{39}$ Belous T. Y. International Industrial Monopolies (rus. Mezhdunarodnyie promyishlennyie monopolii) / T. Y. Belous. - M.: Myisl, 1972. — 277 p. [In Russian].

${ }^{40}$ Karagodin N. A. International Corporations and Social and Political Issues in Developing Countries (rus. Mezhdunarodnyie korporatsii i sotsialno-ekonomicheskie problemyi razvivayuschihsya stran) / N. A. Karagodin. M.: Nauka, 1981. — 196 p. [In Russian].

${ }^{41}$ Astapovich A. Z. Multinational Corporations in the USAL Tendencies and Developmental Inconsistency (rus. Mezhdunarodnyie korporatsii SShA: tendentsii i protivorechiya razvitiya) / A. Z. Astapovich. - M.: Nauka, 1978. - 190 p. [In Russian].

42 Klimko G.et al. International Monopolies' Expansion in the Developing Countries (rus. Ekspansiya mezhdunarodnyih monopoliy v razvivayuschiesya stranyi) / G. N.Klimko, A. I. Rogach, M. Ya. Volkov, M. V. Kollontay. - Vyisshaya shkola, 1989. - 134 p. [In Russian].

${ }^{43}$ Rogach A. I. Expansion of International Monopolies in the Developing Countires of Asia (ukr. Ekspansiya mezhdunarodnyih monopoliy v razvivayuschiesya stranyi Azii) / A. I. Rogach. — K., 1987. — 236 p. [In Ukrainian].

${ }^{44}$ Chibrikov G. G. Contemporary International Monopolies' Role in the Process of Capital and Production Internationalization (rus. Rol sovremennyih mezhdunarodnyih monopoliy $v$ protsesse internatsionalizatsii kapitala $i$ proizvodstva) / G. G. Chibrikov. - Izd-vo MGU, 1979. - 172 p. [In Russian].

45 Belous T. Y. International Monopolies and Outflow of Capital (rus. Mezhdunarodnyye monopolii $i$ vyvoz kapitala) / T. Ya. Belous. - M.. 1982. - 319 p. [In Russian].

${ }^{46}$ Ivanov I. D. International Monopolies in Imperialistic Foreign Policy (rus. Mezhdunarodnyie monopolii vo vneshney politike imperializma) / I. D. Ivanov. — M.: Mezhdunarodnyie otnosheniya, 1981. - p. 8.

47 Ibid.

${ }^{48}$ Ibid, 8-9.
} 
Apparently, it is possible to understand such selectivity, since in those days the main attention was focused on the gigantic international firms of the capitalist countries, which often turned out to be involved in huge political or corruption scandals. Transnational corporations were considered as "private monopolistic corporations, direct and immediate creators of the foreign policy of their countries" 49 . So, in the economic publications of that time, TNCs were considered as part of the "statemonopoly complexes", this group included only "private-ownership companies of the countries of imperialism".

There was proposed a classification of international companies in order to theoretically ground the transition to a new terminology and explain the duality of the names of firms that implement FDI, in the first half of $1980 \mathrm{~s}$ in the domestic literature. It provided that by ownership of capital, companies engaged in international production can be divided into two types: transnational corporations and multinational corporations. It was argued that there are certain differences between them, so it is advisable to distinguish these two types of international firms ${ }^{50}$.

It was considered that transnational companies are national in capital and control, but international in the field of transactions. They have foreign assets on the basis of FDI. Although such corporations create a worldwide network of branches, their mother company is owned by the capital of one country. The "transnational" designation emphasized the connection between the corporation and the capital of a particular nation. Unlike transnational, multinational firms are controlled by the capital of two or more countries. They also have a global network of branches and an international distribution of share capital. The AngloDutch companies "Royal Dutch/Shell" and "Unilever", the GermanBelgian company "Agra-Gewart", the Anglo-Italian company "DunlopPirelli", the Anglo-American-Canadian company "International Nickel Co." and others were specified as an example of multinational firms ${ }^{51}$.

It was noticed that in TNCs, despite of the international diffusion of shares, the main (control) block of shares keeps within the bounds of the home country. Multinational firms have a really international mixing of capital. Although the growth rate of such mixing is growing, the bulk of international firms comes within classification of TNCs. This is due to the fact that combination of the capital of various countries for

\footnotetext{
49 Karaganov S. A. USA: Multinational Corporations and Foreign Policy (rus. SShA: transnatsionalnyie koropratsii $i$ vneshnyaya politika) / S. A. Karaganov. — M.: Nauka, 1984. - pp. 3-7. [In Russian].

50 Rogach O. International Investment: Theory and Practice of Multinational Corporations' Business (ukr. Mizhnarodni investitsiyi: Teoriya ta praktika biznesu transnatsionalnih korporatsiy): Pidruchnik. / O. Rogach. K.: Lybid, 2005. - 720 p. [In Ukrainian]. - p. 31.

51 Rogach O. Transnational Corporations (ukr. Transnatsionalni korporatsiyi) / O. Rogach. - K.: VPT «Kiyivskiy universitet», 2008. — 400 p. [In Ukrainian]. — pp. 17-18.
} 
organization of a globally functioning corporation is a very complicated matter. There are arisen the problems related to various jurisdictions, government policies, double taxation and cross-cultural management ${ }^{52}$. The above classification of firms with international production became the principal in the Ukrainian scientific school of international economics and business during the 1990s and the first decade of the 2000s. It was recorded in the numerous textbooks and teaching guides, scientific articles as an indispensable postulate.

The use of 'transnational corporations' term in domestic economic science reflected certain realities of both the bipolar system of the world economy that existed before the early 1990s and the early stage of the development of international production. The process of internationalization of firms in the 70-80s of the last century just gained strength. De facto, it was still dominated by giants, which were generated by industrialization at the beginning of the twentieth century as well as former colonial commodity companies. They determined the forms and methods of foreign expansion, its strategy and made the greatest impact on countries at this time. As noted by D. Lukianenko, Ya. Stoliarchuk, "the sectoral structure of monopolization of production and capital in this period was represented mainly by raw materials, fuel and energy sectors, as well as primary processing industries" 53 . At the same time, it is normal that the behavior of international giant companies often provoked very close attention on political and public organizations. Therefore, attempts to separate this part of international firms from others seemed quite logical, especially for scientists in the field of political science and international relations.

The terminological differentiation of firms engaged in foreign direct investment also reflected the state of development of the international business science. There are began to form the powerful MNE research schools, which subsequently formulate their essence, methodological characteristics and main features in 1970-1980s. Economic schools of theoretical research of multinational firms are determined with approaches to the classification of such firms, the criteria and essence of these institutions. There were made the first attempts to generalize statistically the scope of activities of multinational firms. The few previous studies have shed some light partially on the process of firms' internationalization.

${ }^{52}$ Rogach O. Transnational Corporations in the World's Economy (ukr. Transnatsionalni korporatsiyi v svitoviy ekonomitsi) / O. Rogach. — K.: «Kiyivskiy universitet», 2005. — 178 p. [In Ukrainian]. — pp. $10-11$.

${ }_{53}$ Lukianenko D., Stoliarchuk Y. Evolution of Socio-Economic Forms of the Erratically Cyclical Development of World's Economy (rus. Evolyutsiya sotsialno-ekonomicheskih form neravnomerno-tsiklicheskogo razvitiya mirovogo hozyaystva). // In: Global Economic Development: Tendencies, Asymmetries, Regulation (rus. Globalnoe ekonomicheskoe razvitie: tendentsii, asimmetrii, regulirovanie) / D. Lukianenko, Ya. Stolyarchuk. - K.: KNEU, 2013. - pp. 308-330. [In Russian]. - pp. 314-315. 
Therefore, the use of the 'transnational corporations' term as the name of the international firms for a long time was quite understandable and justified. This did not prevent researchers from studying of qualitative and quantitative aspects of the influence of these institutions on countries that approve the scale and scope of foreign expansion, and the forms on the directions of capital internationalization. For nearly forty years, UN official publications continued to use the TNCs terminology, reinforcing the scientists' arguments about the existence of various types of international firms.

But, as we have already noted, almost all foreign theoretical schools for studying of the internationalization of capital and production did not accept the TNCs term and continued to use the "multinational corporations" (enterprises, firms) name. Their study of the nature, appearance causes, and main characteristics of international firms did not prove the existence of forcible arguments for dividing these institutions into transnational and multinational companies. Per contra, all courses of the science of international business have come to the decision that the quality features of these firms are the same. They focused on the fact that the essence of companies engaged in foreign business much more accurate and deeper (than the trait of the transnational nature of transactions) characterizes the criteria of multinational production. Without a criterion of multinationality it is impossible to understand the features of the activities of such firms. The multinational activity of these companies, as evidenced by the economic school of an industrial organization, is associated with most of the competitive advantages of such companies. Having regard to this, all fundamental theories of international firms today chose the "multinational enterprises" (firms, corporations, companies) term.

The leader of world science in international business J. Dunning ${ }^{54}$, P. Buckley $^{55}$, A. Rugman ${ }^{56}$, M. Casson and others have always used the term "multinational enterprise (firm)" in their books and articles. A. Rugman believed that the term "multinational enterprise" is more successful methodologically and more closely matches the essence of modern theoretical knowledge about these institutions than the term "transnational corporation". He came into the criticism of many economists over abuse of the term "multinational corporation" and believed that the acceptance of this incorrect name was a mistake of the UN special commission in the early 70s. The main argument of this

\footnotetext{
${ }^{54}$ Dunning J. The Theory of International Production / J. Dunning // International Trade Journal. — 1988. No. 3. - pp.17-26

${ }^{55}$ Buckley P. Internalisation thinking: From the multinational enterprise to the global factory / P. Buckley // International Business Review. - 2009. - No. 18. — pp. 224-235.

56 Rugman A. The regional multinationals: MNEs and 'global' strategic management / A. Rugman. Cambridge University Press. -2005 . -327 p.
} 
criticism is that the term "transnational corporation" focuses only on the exit of the company "beyond national borders or exclusively national interests" 57 . That's why this name has a political science character and satisfies only researchers of political interconnections across state borders. From the point of view of the economy of the firm and the specifics of its foreign transactions, this term has not many benefits.

A. Rugman was one of the first who called into question the appropriateness of determination of the company name with international production on the basis of the criterion, whether these companies are formed as a result of transboundary mergers, crossholding (exchange) of shares of companies of different national affiliations (for example, Unilever and Shell), or are internationalized based on the accretion and investment of the mother company in new projects. He believed that such an approach does not make sense in the world of global mixing of capital, when the heritages of firms pale into significance, and not only giant companies, but also hundreds of medium-sized firms carry out international expansion ${ }^{58}$.

\section{Change of the stereotyped image of an international firm}

Over the forty years since the UN adopted the term "transnational corporations", the perception of researchers about international firms has been changing step by step. During this time, in fact, the science of international business has formed and multinational enterprises are in its focus. As one of the founders of the School of International Business P. Buckley noted, at the beginning of the development of this science, "MNEs were considered as unitary, monolithic companies. The "standard" multinational enterprise came from industrialized countries, was private, industrial, with a homogeneous business culture, and mainly belonged to the capitalists of one state. The refutation of this stereotype took some time until the theory went beyond these artificial boundaries" $" 59$.

Current tendencies in the movement of foreign direct investments and the process of internationalization of enterprises confirm the conclusions of the theory of international business on the priority importance of multinationality in the terminological definition of firms engaged in foreign investment and production activities. A number of

\footnotetext{
${ }^{57}$ Rugman A. Inside the multinationals: the economics of internal markets. 25th anniversary edition / Alan M. Rugman / Palgrave Macmillan, Houndmills, Basingstoke, New York, 2006. — p.10.

${ }_{58}$ Rogach O. International Business Theories (ukr. Teoriyi mizhnarodnogo biznesu) / O. Rogach. - K.: VPT «Kiyivskiy universitet», 2018. — 687 p. [In Ukrainian]. — pp. 141-142.

59 Buckley P. The Contribution of internalization theory to international business: New Realities and unanswered questions / P. Buckley. // Journal of World Business, 2016, V.51. — p.75.
} 
recent publications of R. Narula, A. Verbeke ${ }^{60}$, P. Beamish, D. Chakravarty ${ }^{61}$ shows that multinationality plays even a much larger role in all key areas of MNE activity than in previous times and determines their main competitive advantages. This presents new requirements and challenges for the further evolution of the FDI theory of export and international production. As T. da Silva Lopes, M. Casson, G. Jones investigated in their analysis of the historical development of international business, it was the multinational business that gradually changed the design of connections in the MNE network structures, the structure of their headquarters and the general organizational architecture $^{62}$. New forms of business organization, as shown by D. Lukianenko, increasingly determine its virtualization, "when the physical and legal characteristics of companies are lost when replacing old structures". Network organization of value creation "leads to blurring of borders between companies, the disappearance of the traditional framework between internal and external members of the organization, by large and small firms ${ }^{63}$.

One of the first stereotypes that were quickly disposed by the rapid tendency of internationalization was the criteria based on nationality, company size and industry. Immediately after the World War II, the term of an international company was often identified with the nationality of the United States. Actually, in those days, the export of the direct investments was dominated in the United States and American firms bought up undervalued assets around the world. They used the 1950s and 1960s for worldwide expansionism and entrance of their competitors into the former colonies, based on the hegemony of the US dollar and their technological monopoly.

Not for nothing that in the first theoretical works of R. Vernon ${ }^{64}, \mathrm{H}$. Perlmutter $^{65}$, S. Hymer ${ }^{66}$ these authors pointed that, first of all, international companies are an American phenomenon. For these

\footnotetext{
${ }^{60}$ Narula R. Making internalization theory good for practice: the essence of Alan Rugman's contributions to international business / R. Narula, A. Verbeke // Journal of World Business, No. 50 (4), 2015. - pp. 612-622.

${ }^{61}$ Chakravarty D. Multinational enterprise regional management centres: Characteristics and performance / D. Chakravarty, Y. Hsieh, A. Schotter, A. Beamish // Journal of World Business, 2017, No. 52 (2). — pp. $296-311$.

62 da Silva Lopes T. Organizational innovation in the multinational enterprise: Internalization theory and business history / T. da Silva Lopes, M. Casson, G. Jones // Journal of International Business Studies. - 2018. pp. 1-21. https://link.springer.com/epdf/10.1057/s41267-018-0156-6?

${ }^{63}$ Lukianenko D. Essence and Driving Forces behind Economic Globalism (rus. Harakter i dvizhuschie silyi ekonomicheskogo globalizma) // In: Global Economic Development: Tendencies, Asymmetries, Regulation (rus. Globalnoe ekonomicheskoe razvitie: tendentsii, asimmetrii, regulirovanie / D. Lukianenko. — K.: KNEU, 2013. [In Russian]. - p. 24.

${ }^{64}$ Vernon R. Sovereignty at bay: The multinational spread of U. S. Enterprises / R. Vernon. - New York: Basic Books, 1971. - $336 \mathrm{p}$.

${ }^{65}$ Perlmutter H. The tortuous evolution of the multinational corporation. / H. V. Perlmutter // Columbia Journal of World Business, 1969, January-February, - pp. 9-18.

${ }^{66}$ Hymer S. The International Operations of National Firms: A Study of Direct Investment / S. Hymer. — MIT Press, 1976 . - 253 p.
} 
authors, MNEs were a symbol of American firms. And J. Dunning called his pioneer thesis (hereinafter the book) "American Investment in British Manufacturing Industry (1958) ${ }^{67}$. At that time, all the theoretical and empirical studies of the internationalization of firms were carried out on the basis of US MNE materials. But already in the 1970s, the situation changed dramatically. Then and in the future, Japanese and European firms regained their positions and are regard as a competitor for them. A group of international firms has already acquired a truly multinational character.

One more stereotype was associated with the national strategic orientation of the MNE. As H. Perlmutter proved in his theory of MNE growth stages, these companies are divided into 4 groups ethnocentric, polycentric, regiocentric and geocentric ${ }^{68}$. At a time when a terminological approach to the name of the MNE was developing, a significant part of international by transactions firms were ethnocentric. This meant that they considered the home country as the main center of their activity and the center of the decisions making. The team of senior managers was consisted exclusively of staff from the home country. Moreover, according to the conclusion of D. Westney, S. Zaheer, all the strategic parameters of the company reflected the priority of the home country and the secondary status of "other countries". Abroad, these firms simply copied what they did at home ${ }^{69}$.

The former colonial companies of the metropolitan countries in the extraction industry are a good example of such ethnocentric MNEs. Another example of such ethnocentric firms in the 1960-1970s was also the US international firms, especially in the oil and gas industry. As F. Bergsten, Th. Moran, Th. Horst note, it is unsurprising that such international firms sometimes became the conductor of the policy of their home country, which, in turn, regarded them as an effective foreign policy instrument ${ }^{70}$. So, the political and national component of the activities of the "early" MNEs was quite clear. The term "transnational corporation" in these conditions reflected a certain national and political (ethnocentric) emphasis of these firms. The point was that multinational firms are moving across their national borders, but remain, by J. Behrman's words, "faithful citizens of their

\footnotetext{
${ }^{67}$ Dunning J. American Investment in British Manufacturing Industry / J. H. Dunning. — London, 1958.

${ }^{68}$ Perlmutter $\mathrm{H}$. The tortuous evolution of the multinational corporation. / H. V. Perlmutter // Columbia Journal of World Business, 1969, January-February, - pp. 9-18.

${ }_{69}$ Westney D. The multinational enterprise as an organization / D. Westney, S. Zaheer // In: The Oxford handbook of international business, 2001. - pp. 101-124.

${ }_{70}$ Bergsten C.F. American Multinationals and American Interests / Bergsten C.F., Moran Th., Horst Th. Wash., 1978. - p. 400.
} 
motherland"71. In these circumstances, the logic of the representatives of a group of developing countries, who suggested in the UN commission on multinational corporations to distinguish between international firms of industrialized capitalist countries and their own international companies is clear.

H. Perlmutter in the 1970 s provided that ethnocentric international firms will be replaced by multicentric and then regiocentric and geocentric companies, and multinationality will become the dominant of their strategies, organizational structures and management philosophy ${ }^{72}$. In the early 2000 A. Rugman, A. Verbeke ${ }^{73}$ researches showed that the vast majority of firms with international production radically changed their strategic orientation. These are mainly regiocentric international firms operating in one or two regions. A smaller part of the companies is geocentric - these are real global companies that evenly distribute their production operations and sales across all regions. And a small part of firms focuses only on the home country ${ }^{74}$. So, the national and ideological aspect in the activities of most international enterprises is almost imperceptible. The rest of ethnocentricity of companies can only be seen in multinational firms in developing countries, in the mining industry, where the state has a large share of capital. For example, oil giants Saudi Aramco, Pemex or Petro China always take into account the interests of their home country even when carrying out foreign investment activities.

Before the World War II and in the first post-war decades, architects of international production were mainly big firms. The identification of MNE with giant companies, therefore, had some reasons. In the 1970s UN experts suggested to think that "the main feature of multinational corporations is the presence of large-caliber firms among them ..."75. That is why the first report of UN experts on multinational corporations (1973) mentioned the 650 largest MNEs with sales of more than USD 300 million $^{76}$. Subsequently, during the first report of the UN Commission on Multinational Corporations, it was generally proposed to include only 500 of the largest private companies in industrialized countries among $\mathrm{TNCs}^{77}$. Some futurological works of that time even

\footnotetext{
${ }^{71}$ Behrman J. U.S. International business and governments / J. N. Behrman. — New York: McGraw-Hill Book Co, 1971. - $244 \mathrm{p}$.

${ }_{72}$ Perlmutter H. The Multinational Firms and Future // The Annals of The American Academy / H. Perlmutter., 1972. - pp. 139-152.

73 Rugman A. A new perspective on the regional and global strategies of multinational services firms / A. Rugman, A. Verbeke // Management International Review, 48(4), 2008. - pp. 397-411.

${ }^{74}$ Rugman A. A perspective on regional and global strategies of multinational enterprises / A. Rugman, A. Verbeke // Journal of international business studies, 35(1), 2004. - pp. 3-18.

${ }_{75}^{75}$ UN. Multinational Corporations and World Development / UN. — New York: Praeger Publishers, 1974. — p.7

${ }_{77}^{76}$ Ibid, 127 . Transnational Corporations, $1974 .-$ p. 5.
} 
noted that there will be a "monopoly" in the future when hundreds of firms become the economic owner of the whole world. For example, in 1972 H. Perlmutter predicted that in 30-40 years, "multi-country or cosmopolitan super-giant trans-ideological firms" would reign in the world ${ }^{78}$.

The Brandt Commission, which included famous economists and politicians from many countries, specifically discussed the terminology of international firms in the early 1970s. It also showed that a typical example of discussion was the consideration of TNCs as a large company that operates in the mining or manufacturing industries and in many countries at the same time ${ }^{79}$.

The term "TNC" provided for the selection of all international firms and the spin-off of a group of giant companies that have a great influence on the world economy and host countries from the very beginning of its implementation. One of the critical arguments against the term "multinational enterprises" was that "real international corporations may be "lost"... among many thousands of companies engaged in foreign economic activity" 80 .

But already in the early 1990s, it became clear that the group of international firms is growing at an extremely quick rate, not at the expense of giant companies, but at the expense of so-called international new firms or global firms. According to the pioneers of the study of these untypical international firms, P. McDougall and B. Oviatt ${ }^{81}$, the new participants of the internationalization were different from the "dinosaur" of the early era of internationalization. They were middle or even small in size, flexible, highly mobile and ultrafast in foreign expansion. In the early 1990s, this fact even led to a wide discussion in the world literature on international business: are these real MNEs, or completely new forms of internationalization of capital? According to G. Knight and T. Cavusgil, initiators of such discussion, the question was: should the theory of international business be fundamentally changed to explain these unusual forms of firms internationalization ${ }^{82}$. For almost a decade, there has been a debate among specialists in multinational firms on this issue. In the 2000s, the internationalization of small and medium-sized firms became a mass phenomenon, which

\footnotetext{
${ }^{78}$ Perlmutter H. The Multinational Firms and Future // The Annals of The American Academy / H. Perlmutter., 1972. - pp. 139-152.

79 The Independent Commission on International Development Issues // Secretariat Paper, No 14, — Geneva, 1979. - p. 4

${ }^{80}$ Ivanov I. D. Multinational Corporations in Global Economy (rus. Mezhdunarodnyie korporatsii v mirovoy ekonomike)/ I. D. Ivanov. - M.: Myisl, 1976. - 215 p. [In Russian]. - p.26.

${ }^{81}$ Oviatt B. Toward a theory of international new ventures / B. Oviatt, P. McDougall // Journal of International Business Studies, 1994, Vol. 25, - pp. 45-64.

${ }^{82}$ Knight G., Cavusgil T. The Born Global firm: A challenge to traditional internationalization theory. / G. Knight, S. Cavusgil // Advances in International Marketing, 1996. - pp. 8, 11-26.
} 
gives reason to researchers to believe that the majority (in terms of number) of modern international firms are not giants, but firms with average sizes of international production.

It also became obvious that the boundaries of the MNE are outside the framework of extractive and manufacturing industries, as was believed during the first UN discussions on the name of a typical TNC. The service sector has begun to attract most of the new FDI, and the number of international firms is growing at the fastest rate among all industries here.

The next attribute of the historically politicized definition of TNCs was associated with the private ownership of these firms and the fact that they are exclusively firms of industrialized countries. The internationalization of capital of countries with new markets, countries with economies in transition gave impetus to the existence of a large group of state or private-state international companies. Since the beginning of the 2000s, there was a real "renaissance" of state multinational firms. K. Hee, L. Eden, and M. Gitt research showed that the number of state MNEs is growing steadily, as well as the level of their internationalization. According to the conclusion of these scientists, such institutions represent a hybrid organizational form with dual characteristics of both a state-owned enterprise (SOE) and a multinational enterprise $(\mathrm{MNE})^{83}$.

In the first decade of the 2000s, private-state Chinese international firms had higher growth rates of foreign investment than private companies $^{84}$. Complex forms of internationalization are emerging such as participation in FDI of national sovereign wealth funds or participation in the capital of classical MNE governments of other countries (for example, the Arab countries of OPEC). Although state-owned MNEs, due to significant control of their governments, have a large ethnocentric orientation, the terminological contrast between them and private MNEs is hardly advisable. The patterns, forms and mechanisms of internationalization of both types of firms are becoming more and more similar.

The initial characterization of TNCs, as companies of exclusively industrialized countries, also no longer corresponds to reality. The export of capital from developing countries, countries with a transitional economy and new markets is growing rapidly. This process leads to the emergence of a large number of new international firms. For an increasing number of MNEs, the country of origin is not the

\footnotetext{
${ }^{83}$ Xiaoming H. The renaissance of state-owned multinationals / H. Xiaoming, L. Eden, M. Hitt // Thunderbird International Business Review, 2016, 58 (2). — pp. 117-129.

${ }^{84}$ Ilan Alon. Chinese state-owned enterprises go global / Ilan Alon et al.// Journal of Business Strategy, 2014, Vol. 35, (6), - pp. 3-18.
} 
industrialized states, but the countries of Asia, Africa and Latin America. The tendency has become so widespread that a special UNCTAD report on international investment was even dedicated to this issue $^{85}$. In 2017, 8 of the 100 largest multinational enterprises have primary origin from developing countries ${ }^{86}$. Therefore, the former initiative of Latin American countries to set up international firms of industrialized countries under the special name of TNCs is losing its meaning.

\section{Additional Arguments of Theory and Practice of International Business}

Is it easy to determine the nationality of the MNE?

One of the main criteria of the traditional terminology of firms engaged in international production, and their classification into TNCs and MNEs, differences in the national character of their property were proclaimed. The nationality of FDI firms is usually associated with the legal residence (incorporation) of their owners. But today this is the most vulnerable place for argumentation; "TNCs are firms controlled by the capital of one country, but have branches in other countries". Is it possible to name the international concern Mannesmann as German TNC? Or to name Volvo as a Swedish company, and pharmaceutical giant Sanofi as French TNC? For tens of thousands of firms engaged in international production, the answer on this question is not a simple matter.

For example, Mannesmann concern was a brand of German industry during decades. But in 2000, the British Vodafone Group bought the telecommunications part of this industrial empire for USD 190 billion (this telecommunications division was extremely successful and controlled enterprises not only in Germany, but also in Austria, Italy and the UK). After that, German shareholders owned less than $26.3 \%$ of the shares (Deutsche Bahn - 18.17\% and Deutsche Bank - 8.1\%). Subsequently, another part of the Mannesmann group that produced the pipes was acquired by Austrian capital, which still owns this brand. But the most interesting fact of this story is that even to the takeover in 1999, Hong Kong's Hutchison Whampoa (10.2\% of the capital) was Mannesmann's sole shareholder. Formally significant batch of shares in the concern was held by German investment funds (25\%), but $60 \%$ of the ownership (!) of these funds belonged to foreign companies,

${ }^{85}$ UNCTAD. World Investment Report 2006. FDI from Developing and Transition Economies: Implications for Development / UNCTAD. - Geneva and New York, 2006. - $332 \mathrm{p}$.

${ }_{86}$ UNCTAD. World Investment Report 2018. Investment and New Industrial Policies / UNCTAD. - Geneva and New York, 2018. - p.29. 
including $40 \%$ to investment funds of the USA and Great Britain ${ }^{87}$. Can be Mannesmann called a German TNC after that?

Volvo Group concern, which is the pride of Swedish industry, sold its automotive division Volvo Cars to the American corporation, which is called Ford in 1999, and that, in turn, sold it to the Chinese company which is called Zhejiang Geely Holding in $2010^{88}$. Now this Chinese company controls Volvo brand of motor cars and its production. At the same time, the French Renault became the largest shareholder in the Volvo Group, specializing in motor vans $(21.7 \%)$. Volvo Group sold its Volvo Aero division to the British company GKN in 2018, and in 2019 Volkswagen became the owner of $75 \%$ shares in Volvo's division WirelessCar, which produces telematics for remote control of cars $^{89}$. So, the national ownership structure of this concern is constantly changing and its definition is becoming more and more complicated. Supposedly, many French people still believe that Sanofi pharmaceutical group is "their" company, which has developed international transactions. In fact, $64 \%$ of its shares are held by foreign institutional investors. Only a smaller part of the shares of the largest world food giant Nestle formally owned by residents of Switzerland, although, consumers call it the Swiss MNE by tradition ${ }^{90},{ }^{91}$. And there are a lot of such examples.

Mechanisms of "destruction" by the monoethnic nature of ownership

Although today we can observe that national capitalists hold significant batch of shares in "their" MNEs, the dominant trend is the blurring of the monoethnic nature of ownership of these companies and the rapid increase of the participation of foreign shareholders. Foreign strategic investors, institutional portfolio investors, and even citizens of many countries are composing the modern ownership structure of many MNEs. There is no doubt that this trend will only intensify. Thus, even those firms where the owners of MNE initial origin country still have a controlling batch of shares will fundamentally change the geographical structure of their owners in 5-10 years.

The globalization of financial markets allows international companies to sell their shares on international stock exchanges. Although most of the shares of large American, Japanese, or Chinese firms are traded on their national stock exchanges, an increasing share of MNEs also do

\footnotetext{
${ }^{87}$ Hopner M. Revisiting the Mannesmann takeover: how markets for corporate control emerge / Martin Hopner, Gregory Jackson. European Management Review (2006), 3. — pp. 142-155.

${ }^{88}$ Is Volvo Swedish or Chinese? The Wall Sreet Journal, July 12, 2011

${ }^{89}$ AB Volvo Company Report. https://run.unl.pt/bitstream/10362/49537/1/Onofre 2018.pdf.

90 NSRGY - Nestle SA Shareholders. https://money.cnn.com/quote/shareholders/shareholders.html?symb= NSRGY\&subView=institutional

91 What Kind Of Shareholder Owns Most Nestlé SA (VTX: NESN) Stock? https://finance.yahoo.com/news/ kind-shareholder-owns-most-nestl-090905442.html
} 
likewise on many international financial markets. A huge number of minority shareholders around the world are gradually (though slowly) "eroding the national identity" of such firms. Small companies and global startups immediately acquire the subjects of "multiethnic ownership", as they quickly attract investors from many countries of the world. Consequently, the number of firms with "multiethnic" ownership is growing rapidly, which gives some researchers reason to talk about the dominance or typical nature of this characteristic of capital internationalization at the current stage.

Processes of cross-border mergers and acquisitions (MA) complicate the national identification of an international company even more. They have become widespread over the past thirty years. Over the past fifteen years, the annual volume of this form of capital export has ranged from USD 400 to 600 billion. In 2015-2017, foreign direct investments in the acquisition of existing assets exceeded or was equal to the volume of FDI in new projects ${ }^{92}$. Among the most famous mega- transactions of MA were the acquisition of SABMiller PLC (Great Britain) by Anheuser-Busch Inbev (Belgium, Brazil, USA) in the amount of USD 101 billion $^{93}$, and the pharmaceutical company Allergan PLC (USA) by Teva Pharmaceutical Industries Ltd (Israel) in the amount of 39 USD billion, acquisition of ARM Holdings (Great Britain) by SoftBank Group (Japan) for USD 32 billion, as well as the merger of the American multinational enterprises Dow Chemical and DuPont, resulting in the formation of one of the world's largest chemical conglomerates worth of USD 130 billion $^{94}$. Technically, the execution of such transactions occurs very often due to the exchange of shares (in different proportions) of the participants of spare parts, that is, the multinational structure of their capital is formed.

Deregulation of capital markets and national investment laws in many countries removed obstacles to cross-border capital consolidation. The mass privatization of state-owned companies in countries with emerging economy and new markets spurred this process even more. The result of mergers and acquisitions has become the real multinationality of an increasing number of international firms, cross-ownership of shares batches and an even greater separation of companies from their original "national" basis.

\footnotetext{
${ }^{92}$ UNCTAD. World Investment Report 2018. Investment and New Industrial Policies / UNCTAD. - Geneva and New York: United Nations, 2018. - $192 \mathrm{p}$.

${ }_{93}$ Nurin T. It's Final: AB InBev Closes on Deal To Buy SABMiller. Forbes. - 2016 https://www.forbes.com/sites/taranurin/2016/10/10/its-final-ab-inbev-closes-on-deal-to-buysabmiller/\#72c4188b432c

${ }_{94}$ Dowdupont Merger Successfully Completed. https://corporate.dow.com/en-us/news/press-releases/ dowdupont-merger-successfully-completed
} 
Tax inversions obscure "nationality of a company"

Sometimes the traditional "nationality" of a company is artificially changed due to its tax inversion strategy. Such strategies have spread among international firms over the past twenty years and suggest that the company transfers its tax center to the state, where it makes most of its profits, in a jurisdiction with a lower tax rate. At the same time, a company from a country with a lower tax rate absorbs MNE in a country with a higher tax rate (or the two companies merge). After that, the main (mother) company is the company in the jurisdiction with preferential fiscal mode ${ }^{95}$. The redeployment (legal) of the headquarter demonstrates to the tax authorities of the country with the highest tax rate, that most of the firm's profits made in another jurisdiction, and taxes must be paid there. Since 2005, the number of such corporate inversions has begun to grow significantly (20 large US companies have implemented such measures until 2014) ${ }^{96}$. In 2015, there were eight such transactions worth of USD 63 billion, and in 2016 there were seven, worth of USD 56 billion ${ }^{97}$.

For example, over the past decades, corporate income tax in Ireland was only $12.5 \%$, which was much less than in other countries. Therefore, Ireland was a popular place for corporate inversion for MNE USA and other European countries. So, the American company Eaton Corporation PLC, as a result of a transaction of MA with the Irish Cooper Industries for USD 13 billion, relocated its headquarters to Dublin in 2012. One of the largest US multinational companies of medical equipment manufacturing, Medtronic PLC, having acquired an Irish manufacturer Covidien for USD 49 billion, is now legally considered an Irish company and has a mother company in that country. Consequently, the above American firms formally turned into branches of Irish companies, although the main operational management of their business is carried out from the United States. Considering the formal approaches of the classification for division of such firms into TNCs and MNC, Eaton Corporation and Medtronic should be called as Irish transnational firms (because formally they are owned by owners from Ireland), but this country plays almost no significant role in real management and value creation.

\footnotetext{
95 Slangen A. Disaggregating the corporate headquarters: Investor reactions to inversion announcements by US firms / A. Slangen, M. Baaii, R. Valboni // Journal of Management Studies, 2017, vol. 54(8). — pp. 1241-1270.

96 Marples D. J. Corporate expatriation, inversions, and mergers: Tax issues. / D. J. Marples, J. G. Gravelle. 2014. https://digitalcommons.ilr.cornell.edu/cgi/viewcontent.cgi?referer=https://scholar.google.com.ua/\&httpsredir= $1 \&$ article $=2329 \&$ context $=$ key_workplace.

${ }_{97}$ UNCTAD. World Investment Report 2018. Investment and New Industrial Policies / UNCTAD. - Geneva and New York: United Nations, 2018. - p. 64
} 
FDI transit hubs: change of "national costumes"

The existence of transit stations for the transit of huge volumes of FDI (for example, Hong Kong, Singapore, Netherlands, Ireland, Luxembourg or other offshore jurisdictions) also makes it impossible to accurately determine the capital national origin of a significant number of international firms. There are many examples when MNEs are registered here; in fact, they are belonged to owners groups of completely different countries ${ }^{98}$. Over the past decades, they sent huge amounts of capital resources to offshore financial hubs (offshore financial centers and special corporation centers for accumulating investment resources). Such special corporative institutions (centers) were registered as residents of a given country with one they had almost no economic relations, but are served as holdings of assets of global firms or centers of capital accumulation.

The main attraction of offshore financial centers for MNEs was the possibility of using of low tax rates, regimes of bilateral investment agreements or double taxation agreements, as well as access to the capital resources in international markets. The main recipient of the resources of all multinational enterprise branches, as a rule, were holding companies. It is estimated that about $20 \%$ of all foreign branches of the largest 100 MNEs are located in such "transit hubs". One of the functions of such firm's centers for accumulating investment resources is further foreign investment in new enterprises or cross-border acquisitions of other firms.

For example, in recent years, Hong Kong has been playing the role of the world's third largest recipient of MNE capital. But these huge masses of capital are invested from Hong Kong to other countries. According to the data in Table 1, the volume of investments of multinational firms in Hong Kong reached almost USD 2 trillion in 2017 while at the same time, firms registered here invested USD 180,000,000 outside of Hong Kong.

Table 1

CUMULATIVE VOLUMES OF INFLOW AND OUTFLOW OF FDI FROM HONG KONG (billion dollars)

\begin{tabular}{|l|c|c|c|}
\hline \multicolumn{1}{|c|}{ Years } & 2000 & 2010 & 2017 \\
\hline Accumulated inflow volume of FDI & 435 & 1067 & 1969 \\
\hline Accumulated outflow volume of FDI & 372 & 944 & 1804 \\
\hline
\end{tabular}

Source: UNCTAD. World Investment Report 2014-2018. Geneva and New York: United Nations. - 2014-2018.

${ }^{98}$ Hers J. The Role of Investments Hubs in FDI, Economic Development and Trade: Ireland, Luxembourg, Mauritius, the Netherlands, and Singapore. SEO-report (2018-40) / J. Hers, J. Witteman, W. Rougoor. - 2018. http://www.seo.nl/ uploads/media/2018-40_The_Role_of_Investment_Hubs_in_FDI_Economic_Development_and_Trade.pdf. 
It is not difficult to understand that a significant part of foreign FDI of local firms is a transit movement of capital, originating from other countries. In this case the term TNC only formally corresponds to the traditional classification (TNCs and MNEs), but in fact it conceals the nationality of the real owners of capital. The use of the name "multinational enterprises" in this situation does not have such restrictions, since it implies, among other things, a multiple change in the "national costumes" of firms involved in international production.

\section{Beneficiaries' and Owners' Chains}

So, the issue of national "citizenship" of the MNE is becoming more and more complicated and blurred. The complexity of such an analysis can be understood, considering that 30\% of all foreign MNE branches are directly owned by other local firms of the host country, but these local owners are ultimately controlled by the MNE parent companies ${ }^{99}$. In $41 \%$ of foreign branches, the nationality of the direct and final owner does not coincide. Foreign companies of multinational enterprises often have a concatenation of owners of different nationalities, which is difficult to trace and identify the final beneficiaries. Company $\mathrm{X}$ of country A owns company $\mathrm{Y}$ of country $\mathrm{B}$, and this company is the owner of company $\mathrm{Z}$ in country $\mathrm{C}$. The traditional classification of international firms (their division into two groups - transnational and multinational on the nature of ownership) does not work in this case. In the case of things complication and assumption that company $\mathrm{Z}$ has built enterprises in country $\mathrm{D}$, the situation becomes extremely confusing. The mixing of multiethnic ownership requires a more adequate reflection of this process in the terminology and criteria for the company determination. UNCTAD experts believe that more than $40 \%$ of foreign affiliates are controlled through such complex vertical chains with at least three transit jurisdictions ${ }^{100}$.

It is difficult to trace the national character of the ownership structure of leading US MNEs. The typical picture here is at least two or three levels of cross-ownership of the largest investment funds, a small share of the ownership of management and certain individuals. With the aim to determine the nationality of the ultimate beneficiaries of these companies, it is necessary to investigate "in depth" several levels of portfolio investors, that seems extremely difficult. Thus, from the point of view of the analysis of ownership and distribution of share capital, transnationality, that is, the exit of a company beyond its

\footnotetext{
${ }^{99}$ Avdjiev S. Tracking the international footprints of global firms. / S.Avdjiev, M. Everett, P. Lane, H. Shin. // BIS Quarterly Review, 2018, March. - pp.47-66.

${ }^{00}$ UNCTAD. World Investment Report 2016. Investor Nationality: Policy Challenges / UNCTAD. - Geneva and New York: United Nations, 2016. - p.124, 151
} 
national borders, can no longer be considered as a key feature of such firms and determine their terminological classification ${ }^{10}$.

\section{Multinationality of Venture Startups}

Even more arguments in behalf of the term "multinational enterprise" were provided by the internationalization of medium-sized and small firms. "New international enterprises" or firms "born global" are small in the beginning of their ultrafast internationalization and often remain so in the future. As G. Knight and T. Cavusgil analyzed, firms which were born global proclaim themselves not as transnational, but exclusively as "multinational" institutions ${ }^{102}$. This is due not only to the fact that venture capital investors from many countries dominate in the structure of their owners, but also to the fact that they immediately go through the phase of an ethnocentric strategy and start a global business based on multinational production outsourcing and service networks. Often, international startups change their "national registration" and majority owners several times in a relatively short time. They even physically relocate their main companies to other countries, adapting to the requirements of global competition ${ }^{103}$. Skype, the world's largest international voice operator, grew up from a startup set up by Estonian, Swedish, Danish partners and American venture capitalist Howard Gartenbauer ${ }^{104}$. Skype immediately became multinational in both transactions and ownership. But subsequently, several new owner changes occurred - eBay (2005), a group of global venture funds (2009), and finally, in 2011, the American Microsoft became its owner. The company's center has moved from Tallinn to Luxembourg.

Network-based multinational knowledge generation process

The networked nature of innovations creation of modern international companies further "diffuses" their belonging to certain countries. The modern paradigm of international firms' knowledge generation involves the active internationalization of this process. B. Kogut, U. Zander pioneering studies showed that the defining feature of an international company is the special nature of knowledge generation. In contrast to the situation that existed 40-50 years ago, the main feature of a modern

101 Rogach O. Multinational Enterprises (ukr. Bagatonatsionalni pidpriemstva). Pidruchnik. / Oleksandr Rogach. - Kyiv: VPT «Kiyivskiy universitet», 2019. — 387 p. [In Ukrainian].

102 Knight G. Innovation, organizational capabilities, and the born-global firm / G. Knight, T. Cavusgil // Journal of International Business Studies, 2004, Vol.35. — pp. 124-141.

${ }^{103}$ Rasmussen E. The emergence of the lean global start-up as a new type of firm. / E. Rasmussen, S. Tanev // Technology Innovation Management Review, 2015, 5(11), pp.12-19.

${ }^{104}$ Bharat Rao. Fusion of Disruptive Technologies: Lessons from the Skype Case / Bharat Rao, Bojan Angelov, Oded Nov // European Management Journal, 2006, Volume 24, Issues 2-3. - pp. 174-188. 
international company is precisely the multinational nature of this process $^{105}$. The knowledge-based MNE theory argues that the foreign divisions of a firm generate no less important knowledge and competencies of these firms than the "home" enterprises of the mother company. Moreover, as N. Foss and T. Pederson have proved, the key knowledge of such firms is generated not only by their foreign branches, but also by independent subcontracted partners of many countries ${ }^{106}$.

\section{Multinational Management Teams}

Finally, multinationality, but not transnationality of strategic management, organizational culture and management teams is another essential characteristic of modern international firms. According to $\mathrm{H}$. Perlmutter, the transnational nature of management teams means the dominance of the organizational culture of the home country. As already shown by us earlier, it was a subject of early international firms that were ethnocentric. The opinion, that firms, engaged in international production, can hardly be considered as a category of specific nationality, was firmly established in the world scientific literature on strategic management of MNE as early as the beginning of the $1990 \mathrm{~s}^{107}$. A key feature of modern MNEs is the attraction of the most talented, endow personnel from the global labor market, the formation of multinational management teams, including the highest level. That is why cross-cultural management is becoming extremely important today for the effective operation of the MNE and the implementation of their international strategies.

\section{Multinational Process of Value Creation}

But the most expressive evidence of the priority of multinationality, as a terminological key feature of modern firms engaged in direct foreign investment and foreign expansion, is the multinational value creation process. The theory of fragmentation of international production, the various courses of its are developed by G. Grossman, E. Rossi-Hansberg ${ }^{108}$, G. Gefferi, T. Sturgeon ${ }^{109}$ and others, covers the study of the functional and geographical segmentation of transactions to increase the cost of goods and services, the spatial clustering of firms, economic distance between

${ }^{105}$ Kogut B. Knowledge of the Firm and the Evolutionary Theory of the Multinational Corporation / B. Kogut, U. Zander // Journal of International Business Studies, 1993, Vol. 24, - pp. 625-646.

106 Foss N. J. Transferring Knowledge in MNCs: The Role of Sources of Subsidiary Knowledge and Organizational Context / Foss N. J., Pederson T // Journal of International Management, 2002, vol. 8. - pp. 49-67.

${ }_{107}$ Rogach O. TNC and Economic Growth of the Developing Countries (ukr. TNK $i$ ekonomichne zrostannya krayin, scho rozvivayutsya)/ O.I. Rogach. - K.: Kniga, 1994. - 385 p. [In Ukrainian]. — p. 31.

${ }_{108}$ Grossman G. Task trade between similar countries / G. Grossman, E. Rossi-Hansberg // Econometrica. 2012. - Vol. 80. -№2. - pp. 593 - 629.

109 Gereffi G. The governance of global value chains / Gereffi G., Humphrey J., Sturgeon T.// Review of International Political Economy. February 2005. — Vol.12, № 1, 2005. - pp. 78-104. 
foreign locations and problems of strategic management of value-added networks of companies. Taking into account the achievements of these modern studies, an attempt to explain the global chains of production, supply and outsourcing as "transnational networks" will not be successful. The recognition of the multinational character of such an organizational architecture looks much more logical.

Global value chains (GVC) are the foundation of the organizational structure of many sectors of the world economy today ${ }^{110}$. They function as multinational network structures that assign only a part of the value creation process to each nation. Fragmentation of international production has significantly changed the global economy architecture. Sometimes MNEs act only as "conductors" of such value chains. Almost all researchers of international business agree that the multinational creation of value is the main feature of the organizational, management systems and strategies of international companies today. Therefore, this fundamental characteristic should be indicated as a priority feature of the essence of these companies and is reflected in their name.

The term transnational corporation is rather evidenced by the outside of the matter. It tells about the dynamics of the company's movement, its desire to create value beyond national borders. But it does not characterize the main essential aspect of this process - a multi-stage, geographically dispersed and functionally fragmented process of increasing value, which covers different countries. The name "Multinational enterprises" focuses on this aspect of the value creation process, which includes the factors of production of many nations. Moreover, it is quite universal, because it does not deny the constant spatial restructurisation of global value chains, which is another feature of modern international firms.

For example, the trade war between the United States and China caused today the largest organizational reorganization of the many MNEs value creation process, primarily American firms, over the past twenty years. The transfer of individual fragments production of value from the PRC to other countries (for example, Vietnam) changes the geographical configuration of GVC, but does not deny the multinational nature of the process. The existence of multinational production will determine in the future the specific features of the MNE as a form of structural business organization: their organizational models, entrepreneurial strategy, directions of internal corporate movement of goods and financial resources.

Thus, modern theoretical approaches to the internationalization of firm's study- the term of international new (or born global) enterprises,

\footnotetext{
110 Rogach O. Multinational Enterprises (ukr. Bagatonatsionalni pidpriemstva). Pidruchnik. / Oleksandr Rogach. — Kyiv: VPT «Kiyivskiy universitet», 2019. — 387 p. [In Ukrainian]. — pp.101-104.
} 
the network theory of international business, the knowledge-based MNE theory, the fragmentation of international production theory proclaim multinationality as the key characteristic of modern international firms. Modern business practices of firms engaged in foreign direct investments also provide additional arguments in favor of the term "Multinational enterprises".

\section{Quantitative indicators as criteria for MNE identification}

In some domestic scientific and educational publications, there is payed attention to quantitative indicators, for example, the number of foreign countries of transactions, part of foreign assets or sales, and the share of control in the share capital of other firms in the process of determination and classification of firms engaged in international production. This approach was common in the 1970s and 1980s and it is based on the methodology of the Harvard project on multinational enterprises, popularized by $R$. Vernon. But even at that times this famous scientist called for extreme caution in treating of such statistical indicators of multinationality. Today, no one MNE theoretical research school uses quantitative indicators as important signs of these institutions identification.

The main criterion for MNE determination is the previously mentioned quality features of these enterprises. Quantitative indicators are only additional, secondary signs of classification of a multinational company. For example, determination of the minimum number of foreign branches or the number of countries where the transactions are carried out. This is done only in order to highlight the most MNEs and not to include those companies that have, for example, one foreign branch in the groups of multinational firms, as well as to determine the degree of internationality of the company.

Quantitative indicators include the volume of foreign production, FDI, assets, sales, profit and the share of these indicators in the aggregate corporate data. Each of these indicators is informative in its own way and gives a statistical characteristic of individual aspects of the growth and internationalization of firms. However, the significance of quantitative criteria should not be overcharged. These indicators of "internationality" are rather arbitrary and vary by individual industries and fields of activity. Isolated, uncoupled from the main qualitative characteristics, they cannot be the basis for BNP determination ${ }^{111}$.

111 Rogach O. Globalization of Production and Capital (ukr. Globalizatsiya virobnitstva ta kapitalu) // In: World's Economy (ukr. Svitova ekonomika). Pidruchnik. Za redaktsieyu O.I. Shnirkova, V.I. Mazurenka, O.I. Rogacha. / O. Rogach. - K.: VPT «Kiyivskiy universitet», 2018. - 607 p. [In Ukrainian]. - pp. 224-225. 
It is worth to make reference to very simple definition of MNE, which the EU group gives in its glossary on the official Eurostat website: "Multinational enterprise" $e^{12}$, abbreviated as MNE and sometimes called as multinational corporation (MNC) or an international corporation, is an enterprise that produces goods or services more than in one country. A multinational enterprise has its headquarter in one (or less, more than one) country, home country, and also operates in other countries, host countries"113.

One more comprehensive definition of $\mathrm{MNE}$ is in the last edition (2017) of the "Tripartite Declaration of Principles Relating to Multinational Corporations and Social Policy" of the International Labor Organization: "The term of multinational enterprises includes enterprises (our italic type - O. Rohach) - regardless of whether they are fully or partially public or private, owning or controlling production, distribution, services or other facilities outside the country in which they are based. They can be large or small and have headquarter in any country in the world. The degree of autonomy of entities in multinational enterprises in relation to each other varies widely from one such enterprise to another, depending on the nature of relations between such entities and their field of activity, given the great diversification in ownership, size, nature and place of business" 114 .

As we can see, in all these definitions there is no mention of either transnationality and TNCs, or quantitative indicators of foreign transactions. So, the features of modern internationalization of the world economy, the involvement of medium and even small companies in this process obligate to reconsider the values of the quantitative characteristics of MNE. The theory of international business should give answers to such changes in the categories of multinational enterprises and establish the reasons for successful international transactions of firms that fundamentally differ from traditional MNE giants.

\section{Conclusion}

In the procedure of TNCs term adoption by UN experts, there are played a significant role the political and even ideological considerations, rather than inherent economic criteria for firms' determination engaged in international production. One aspect of this decision was the intention to show the difference between international companies of industrial

\footnotetext{
${ }^{112}$ Demi bold and italic type as marked by EU experts.

113 EU. Glossary: Multinational enterprise (MNE). Eurostat https://ec.europa.eu/eurostat/statisticsexplained/index.php/Glossary:Multinational enterprise (MNE)

14 ILO. Tripartite Declaration of Principles Concerning Multinational Enterprises and Social Policy. International Labour Office, ILO, 2017. — p.3. https:/www.ilo.org/wcmsp5/groups/public/---ed_emp/---emp_ent/--multi/documents/publication/wcms_094386.pdf.
} 
developed countries and developing countries, or former socialist countries. At the same time, TNCs were considered as an integral part of the foreign policy of the capitalist countries and its instrument. The standard idea of transnational firms was based on the fact that these are, first of all, giant companies (from 25 to 500 largest firms in the world), which simultaneously operate in at least 20 countries of the world.

The disappearance of the bipolar political and economic system fundamentally changed the investment environment of the former socialist countries and developing countries. In almost all countries of the world, multinational enterprises are no longer regarded as the "Trojan horse of imperialism". Over the past thirty years, these countries have consistently liberalized investment laws and have encouraged the flow of direct investments in their economies. In particular, the former political and ideological motives for the argumentation of the term "TNC" lose their meaning. This does not mean that states do not follow their national interests or naively idealize multinational firms. Of course, even today, it is impossible to reject completely the concern of countries regarding the possible political consequences of the MNE. But usually it is about pragmatic business relationships that have benefits for both parties.

Overall, it allows to make the main emphasis on the analysis of the essence and terminological certainty of international firms on the economic processes of their growth and transactions. And the main feature of modern international firms - the multinational process of value creation comes to the foreground. All major schools of the firms' internationalization research note the priority of this category in understanding of the modern features of foreign investment and production transactions of firms, although they focus on its various aspects.

It should also be noted that the term "TNC" implies the existence of a corporation, that is, corporate ownership. Most modern multinational production firms are joint-stock companies. But some of these companies do not have the legal form of corporations. Modern multinational startups often emerge as share limited liability companies. There are other forms of business organization. That is why the economic literature on the problems of capital internationalization usually uses the names "company", "enterprise", which allow to avoid misunderstandings of legal identification of these institutions. The name "multinational enterprise", in this sense, is more flexible and broad. Not all companies engaged in international business are corporations, but all of them are enterprises. Moreover, the word "enterprise" additionally focuses on the economic aspect of the analysis, because it involves the process of value creation.

There is a question - what about the term "transnationalization", which is also gradually inculcated in the domestic scientific and 
educational literature? Its use is derived from the term "TNC". Therefore, a more logical, accurate, and informative substitute for this name is the term "internationalization of firm (capital, world economy, etc.)". By the way, the term "transnationalization" is practically not used in foreign economic studies, or is even much less common than the term "TNC". You will hardly find such a name in a foreign textbook on international business or in a theoretical article about these problems. It is quite logically and successfully replaced by the term of internationalization of capital or internationalization of a firm.

A scientific economic analysis of the process of production and capital internationalization requires that the main focus of the analysis should be not on the political, externally organizational, or technical and economic conditions for this process determination, but on the essential micro and macroeconomic conditions for international business activity forms identification. From this point of view, the criterion of multinationality (transactions, value creation, management, knowledge generation, tax and cultural environment, etc.) provides the researcher with much more opportunities to understand more deeply the current tendencies of capital export and the international production transaction.

So, although it is still possible to see various definition of firms which organize international production, the vast majority of editions of foreign educational and scientific literature on international business use the term of multinational enterprises or firms. One of the leading UNCTAD publications on this issue, "UNCTAD World Investment Report", has abandoned the name "TNC" and uses the term "multinational enterprises" in current official publications of this organization. ${ }^{115}$. The main emphasis in this name is made on the multinationality of value creation, and not on the monoethnic origin or ownership of firms. The World Trade Organization (WTO) has also changed the term "TNC" to the name of "multinational enterprises (firms)". Our frequency analysis of these definitions using in the WTO documents, speeches and discussions of the members of this organization showed that $81 \%$ of such cases (in 2000-2019) are accounted for by the $\mathrm{MNE}^{116}$. All recent WTO reports and statements contain the term "multinational enterprises (firms)" ${ }^{117} ; 118$. The European Union also uses the name "multinational enterprises" in its official publications".

${ }^{115}$ UNCTAD. World Investment Report 2017: Investment and the Digital Economy / UNCTAD. — Geneva and New York: United Nations, 2017. - pp. 2-25.

${ }^{116}$ According to our estimations, there were 10582 cases of all types of terms' usage as of July 1, 2019. In particular: MNE - 6349, MNC - 2281, TNC - 1952. https://www.wto.org/

117 WTO. World Trade Report 2018 / WTO, Geneva, 2018. - p. 18, 108, 109. https://www.wto.org/ english/res_e/publications_e/world_trade_report18_e.pdf

118 WTO. World Trade Report 2017 / WTO, Geneva, 2017. - p. 119, 139. https://www.wto.org/ english/res_e/booksp_e/world_trade_report17_e.pdf 
Taking into account the need for further integration of the Ukrainian international business school into the world scientific space, it is advisable for domestic scientists to accept the above methodological and terminological conclusions of long-term foreign studies of the internationalization of firms and to recognize the term "multinational enterprise" as the most accurate and meaningful in relation to all institutions, engaged in foreign production, based on FDI. It is time to think about whether there are significant scientific arguments in the Ukrainian international business school to stand aside the global terminological approaches in relation to the name of multinational enterprises.

\section{References}

1. AB Volvo Company Report. https://run.unl.pt/bitstream/10362/ $49537 / 1$ /Onofre 2018.pdf.

2. Astapovich A. Z. Multinational Corporations in the USAL Tendencies and Developmental Inconsistency (rus. Mezhdunarodnyie korporatsii SShA: tendentsii i protivorechiya razvitiya) / A. Z. Astapovich. - M.: Nauka, 1978. - 190 p. [In Russian].

3. Avdjiev S. Tracking the international footprints of global firms. S. Avdjiev, M. Everett, P. Lane, H. Shin. / / BIS Quarterly Review, 2018, March. - C.47-66. Belous T. Y. Mezhdunarodnyie monopoliy i vyivoz kapitala T. Y. Belous. - M., 1982. - 319 p. [In Russian].

4. Barnet R. Global Reach: The Rise of the Multinational Corporation R. Barnet, R. Muller. - New York, 1974.

5. Behrman J. U.S. International business and governments

J. N. Behrman. - New York: McGraw-Hill Book Co, 1971. - 244 pp.

6. Belous T. Ya. International Industrial Monopolies (rus. Mezhdunarodnyie promyishlennyie monopolii) / T. Ya. Belous. - M.: Myisl, 1972. - 277 p. [In Russian].

7. Belous T. Ya. International Monopolies and Outflow of Capital (rus. Mezhdunarodnyye monopolii $i$ vyvoz kapitala) / T. Ya. Belous. - M. 1982. 319 p. [In Russian].

8. Bergsten C.F. American Multinationals and American Interests Bergsten C.F., Moran Th., Horst Th. - Wash., 1978. - 400 p.

9. Bharat Rao. Fusion of Disruptive Technologies: Lessons from the Skype Case // European Management Journal, Vol. 24, Issues 2-3 / Bharat Rao, Bojan Angelov, Oded Nov. - pp. 174-188.

10. Buckley P. Internalization thinking: From the multinational enterprise to the global factory / P. Buckley. / / International Business Review. - 2009. No. 18. - pp. $224--235$.

11. Buckley $\mathrm{P}$. The Contribution of internalization theory to international business: New Realities and unanswered questions / P. Buckley. / / Journal of World Business 2016, Vol.51. - pp. 74-82.

12. Buckley P. The Future of the Multinational Enterprise / P. Buckley, M. Casson. - New York: The McMillan Company, 1976. 
13. Chibrikov G. G. Contemporary International Monopolies' Role in the Process of Capital and Production Internationalization (rus. Rol sovremennyih mezhdunarodnyih monopoliy $v$ protsesse internatsionalizatsii kapitala $i$ proizvodstva) / G. G. Chibrikov. - Izd-vo MGU, 1979. - 172 p. [In Russian].

14. Klimko G.et al. International Monopolies' Expansion in the Developing Countries (rus. Ekspansiya mezhdunarodnyih monopoliy v razvivayuschiesya stranyi) / G. N.Klimko, A. I. Rogach, M. Ya. Volkov, M. V. Kollontay. Vyisshaya shkola, 1989. - 134 p. [In Russian].

15. da Silva Lopes T. Organizational innovation in the multinational enterprise: Internalization theory and business history / T. da Silva Lopes, M. Casson, G. Jones / / Journal of International Business Studies. - 2018. pp. $1-21$.

16. DowDuPont Merger Successfully Completed. https://corporate.dow.com/ en-us / news / press-releases / dowdupont-merger-successfully-completed.

17. Dunning J. American Investment in British Manufacturing Industry J. H. Dunning. - London, 1958.

18. Dunning J. (Ed.). International investment: selected readings / Dunning J. H. (Ed.). - Penguin, 1972.

19. Dunning J. The Theory of International Production / J. Dunning. / / International Trade Journal. - 1988. - No. 3. - pp. 17-26.

20. ECOSOC. Res. 1913(LVII) / ECOSOC.

21. EU. Glossary: Multinational enterprise (MNE). Eurostat. https: / / ec.europa.eu/eurostat/statistics-explained/index.php/Glossary:Multinational_ enterprise_(MNE).

22. EU. Multinational Enterprise Groups and Their Structure. / EU, EUROSTAT https://ec.europa.eu/eurostat/web/experimental-statistics / multinational-enterprise-groups

23. Foss N. J. Transferring Knowledge in MNCs: The Role of Sources of Subsidiary Knowledge and Organizational Context / / Journal of International Management, Vol. 8/ Foss N. J., Pederson T., 2002. - pp. 49-67.

24. Gereffi G. The governance of global value chains $/ /$ Review of International Political Economy. February 2005. - Vol.12. - 1 / Gereffi G., Humphrey J., Sturgeon T., 2005. - pp. 78-104.

25. Gilpin R. US Power and the Multinational Corporations: The Political Economy of Foreign Direct Investment / R. Gilpin, W. Gilpin. - New York: Basic Books, 1975.

26. Grossman G. Task trade between similar countries / / Econometrica, Vol. 80. - No. 2 / G. Grossman, E. Rossi-Hansberg., 2012. - pp. 593 - 629.

27. Hers J. The Role of Investments Hubs in FDI, Economic Development and Trade: Ireland, Luxembourg, Mauritius, the Netherlands, and Singapore. SEOreport (2018-40) / J. Hers, J. Witteman, W. Rougoor. - 2018. http: / / www.seo.nl/uploads/media/2018-40_The_Role_of_Investment_Hubs_in_ FDI_Economic_Development_and_Trade.pdf.

28. Hopner $\bar{M}$. Revisiting the Mannesmann takeover: how markets for corporate control emerge / / European Management Review (2006). No. 3 / Martin Hopner, Gregory Jackson., 2006. - pp. 142-155.

29. Hymer S. The efficiency (contradictions) of multinational corporations. / The American Economic Review, 60(2) / S. Hymer., 1970. - pp. 441-448. 
30. Hymer S. The International Operations of National Firms: A Study of Direct Investment / S. Hymer. - MIT Press, 1976. - 253 p.

31. Hymer S. The internationalization of capital //Journal of Economic Issues, 6(1) / S. Hymer., 1972. - pp. 91-111.

32. Ilan Alon et al. Chinese state-owned enterprises go global / / Journal of Business Strategy 35.6 / Ilan Alon et al., 2014. - pp. 3-18.

33. ILO. Tripartite Declaration of Principles concerning Multinational Enterprises and Social Policy / International Labour Office. - Geneva, 2017. https: / /www.ilo.org/wcmsp5/groups / public/---ed_emp/---emp_ent/---multi / documents / publication/wcms 094386.pdf.

34. Ingram G. Expropriation of U.S. Property in South America G.M. Ingram. - New York: L., 1974. - pp. 303-304.

35. Is Volvo Swedish or Chinese? / / The Wall Street Journal, July 12, 2011.

36. Ivanov I. D. Multinational Corporations in Global Economy (rus. Mezhdunarodnyie korporatsii v mirovoy ekonomike) / I. D. Ivanov. - M.: Myisl, 1976. - 215 p. [In Russian].

37. Ivanov I. D. International Monopolies in Imperialistic Foreign Policy (rus. Mezhdunarodnyie monopolii vo vneshney politike imperializma) I. D. Ivanov. - M.: Mezhdunarodnyie otnosheniya, 1981. - 174 p. [In Russian].

38. Karaganov S. A. USA: Multinational Corporations and Foreign Policy (rus. SShA: transnatsionalnyie koropratsii $i$ vneshnyaya politika)

S. A. Karaganov. - M.: Nauka, 1984. - pp. 3-7. [In Russian].

39. Karagodin N. A. International Corporations and Social and Political Issues in Developing Countries (rus. Mezhdunarodnyie korporatsii $i$ sotsialnoekonomicheskie problemyi razvivayuschihsya stran) / N. A. Karagodin. - M.: Nauka, 1981. - 196 p. [In Russian].

40. Kindleberger C. American Business Abroad. Six Lectures on Direct Investment. New Haven and London / Ch. Kindleberger. - Yale University Press, 1969. - 210 p.

41. Knickerbocker F. Oligopolistic Reaction and Multinational Enterprise F. T. Knickerbocker. - Cambridge, MA: Harvard Business School Division of Research, 1974.

42. Knight G. Innovation, organizational capabilities, and the born-global firm / G. Knight, T. Cavusgil // Journal of International Business Studies, 2004, vol.35. - pp. 124-141.

43. Knight G., Cavusgil T. / / The Born Global firm: A challenge to traditional internationalization theory. Advances in International Marketing / G. Knight, S. Cavusgil., 1996. - pp. 8, 11-26.

44. Kogut B. Knowledge of the Firm and the Evolutionary Theory of the Multinational Corporation / / Journal of International Business Studies, Vol. 24 / B. Kogut, U. Zander., 1993. - pp. 625-646.

45. Lamy P. Sports equipment typifies new global production pattern. https: / / www.wto.org/english/news_e/sppl_e/sppl185_e.html.

46. Lukianenko D. Essence and Driving Forces behin̄ Economic Globalism (rus. Harakter i dvizhuschie silyi ekonomicheskogo globalizma) / / In: Global Economic Development: Tendencies, Asymmetries, Regulation (rus. Globalnoe ekonomicheskoe razvitie: tendentsii, asimmetrii, regulirovanie D. Lukianenko. - K.: KNEU, 2013. - pp. 19-35. [In Russian]. 
47. Lukianenko D., Stoliarchuk Y. Evolution of Socio-Economic Forms of the Erratically Cyclical Development of World's Economy (rus. Evolyutsiya sotsialnoekonomicheskih form neravnomerno-tsiklicheskogo razvitiya mirovogo hozyaystva). / / In: Global Economic Development: Tendencies, Asymmetries, Regulation (rus. Globalnoe ekonomicheskoe razvitie: tendentsii, asimmetrii, regulirovanie) D. Lukianenko, Ya. Stolyarchuk. - K.: KNEU, 2013. - pp. 308-330. [In Russian].

48. Marples D. J. Corporate expatriation, inversions, and mergers: Tax issues. D. J. Marples, J. G. Gravelle. - 2014. https://digitalcommons.ilr.cornell.edu / cgi / viewcontent.cgi? referer=https: / / scholar.google.com.ua/\&httpsredir=1\&artic $\mathrm{le}=2329 \&$ context $=$ key workplace.

49. Multinational enterprise regional management centers: Characteristics and performance / D. Chakravarty, Y. Hsieh, A. Schotter, A. Beamish / / Journal of World Business / D.Chakravarty, Y. Hsieh, A. Schotter, A. Beamish., 2017. pp. 296-311, 52 (2).

50. Narula R. Making internalization theory good for practice: the essence of Alan Rugman's contributions to international business J / R. Narula, A. Verbeke $/ /$ Journal of World Business, 50 (4) / R. Narula, A. Verbeke, 2015. pp. $612-622$.

51. NSRGY - Nestle SA Shareholders. https://money.cnn.com/quote/ shareholders / shareholders.html? symb=NSRGY \&subView=institutional.

52. Nurin T. It's Final: AB InBev Closes on Deal to Buy SABMiller. Forbes. - 2016. -https://www.forbes.com/sites/taranurin/2016/10/10/itsfinal-ab-inbev-closes-on-deal-to-buy-sabmiller /\#72c4188b432c.

53. OECD. OECD Guidelines for Multinational Enterprises. 2011 Edition. https: / / www.oecd.org/daf/inv/mne/48004323.pdf.

54. OECD. The OECD Declaration and Decisions on International Investment and Multinational Enterprises: Basic Texts. https://www.oecd.org/ $\mathrm{daf} / \mathrm{inv} /$ investment-policy / ConsolidatedDeclarationTexts.pdf.

55. Oviatt B. Toward a theory of international new ventures. / / Journal of International Business Studies, 25 / B. Oviatt, P. McDougall., 1994. - pp. 45-64.

56. Perlmutter H. The Multinational Firms and Future / / The Annals of The American Academy / H. Perlmutter., 1972. - pp. 139-152.

57. Perlmutter $\mathrm{H}$. The tortuous evolution of the multinational corporation. Columbia Journal of World Business / H. V. Perlmutter., 1969. - pp. 9-18.

58. Rasmussen E. The emergence of the lean global startup as a new type of firm. / / Technology Innovation Management Review, 5(11). / E. Rasmussen, S. Tanev, 2015.

59. Rogach O. Multinational Enterprises (ukr. Bagatonatsionalni pidpriemstva). Pidruchnik. / Oleksandr Rogach. - Kyiv: VPT «Kiyivskiy universitet», 2019. - 387 p. [In Ukrainian].

60. Rogach O. International Business Theories (ukr. Teoriyi mizhnarodnogo biznesu) Y O. Rogach. - K.: VPT «Kiyivskiy universitet», 2018. - 687 p. [In Ukrainian].

61. Rogach O. Globalization of Production and Capital (ukr. Globalizatsiya virobnitstva ta kapitalu) / In: World's Economy (ukr. Svitova ekonomika). Pidruchnik. Za redaktsieyu O.I. Shnirkova, V.I. Mazurenka, O.I. Rogacha. O. Rogach. - K.: VPT «Kiyivskiy universitet», 2018. - 607 p. [In Ukrainian]. 
62. Rogach O. Transnational Corporations (ukr. Transnatsionalni korporatsiyi) / O. Rogach. - K.: VPT «Kiyivskiy universitet», 2008. - 400 p. [In Ukrainian].

63. Rogach O. International Investment: Theory and Practice of Multinational Corporations' Business (ukr. Mizhnarodni investitsiyi: Teoriya ta praktika biznesu transnatsionalnih korporatsiy): Pidruchnik. / O. Rogach. - K.: Lybid, 2005. - 720 p. [In Ukrainian].

64. Rogach O. Transnational Corporations in the World's Economy (ukr. Transnatsionalni korporatsiyi $v$ svitoviy ekonomitsi) / O. Rogach. - K.: «Kiyivskiy universitet», 2005. - 178 p. [In Ukrainian].

65. Rogach O. TNC and Economic Growth of the Developing Countries (ukr. TNK $i$ ekonomichne zrostannya krayin, scho rozvivayutsya) / O.I. Rogach. K.: Kniga, 1994. - 385 p. [In Ukrainian].

66. Rogach A. I. Expansion of International Monopolies in the Developing Countires of Asia (ukr. Ekspansiya mezhdunarodnyih monopoliy $v$ razvivayuschiesya stranyi Azii) / A. I. Rogach. - K., 1987. - 236 p. [In Ukrainian].

67. Rugman A. A new perspective on the regional and global strategies of multinational services firms / / Management International Review 48(4) / A. Rugman, A. Verbeke., 2008. - pp. 397-411.

68. Rugman A. A perspective on regional and global strategies of multinational enterprises / / Journal of International Business Studies, 35(1) / A. Rugman, A. Verbeke., 2004. - pp. 3-18.

69. Rugman A. Inside the multinationals: the economics of internal markets / Alan M. Rugman. - Houndmills, Basingstoke, New York: Palgrave Macmillan, (25th anniversary ed.), 2006. - 164 p.

70. Rugman A. The regional multinationals: MNEs and 'global' strategic management / A. Rugman. - Cambridge University Press, 2005. - 327 p.

71. Slangen A. Disaggregating the corporate headquarters: Investor reactions to inversion announcements by US firms / / Journal of Management Studies, 54(8) / A. Slangen, M. Baaij, R. Valboni., 2017. - p. 1241-1270.

72. Stopford J. Managing the multinational enterprise: Organization of the firm and ownership of the subsidiary. / J. Stopford, L. Wells Jr., 1972.

73. The Independent Commission on International Development Issues / / Secretariat Paper, No. $14 /$ The Independent Commission on International Development Issues. - Geneva, 1979.

74. Turner L. Invisible empires: Multinational companies and the modern world / L. Turner, 1970.

75. Turner L. Multinational Companies and the Third World / L. Turner. New York, 1973. 1969.

76. Turner L. Politics and the Multi-national Company / L. Turner - L.,

77. UN Commission on Transnational Corporations. / / Conference Room Paper No. 6 / UN Commission on Transnational Corporations, 1974.

78. UN. Multinational Corporations and World Development / UN. - New York: Praeger Publishers, 1974. - 232 p.

79. UN. Summary of the Hearings before the Group of Eminent Persons to Study the Impact of Multinational Corporations on Development and on International Relations / UN. - New York, 1974. 
80. UN. The Impact of Multinational Corporations on Development and on International Relations / UN. - New York, 1974.

81. UNCTAD. World Investment Report 2016. Investor Nationality: Policy Challenges / UNCTAD. - Geneva and New York: United Nations, 2016. - 186 p.

82. UNCTAD. World Investment Report 2017: Investment and the Digital Economy / UNCTAD. - Geneva and New York: United Nations, 2017. - 236 p.

83. UNCTAD. World Investment Report 2018. Investment and New Industrial Policies / UNCTAD. - Geneva and New York: United Nations, 2018. - 192 p.

84. UNCTAD. World Investment Report 2006. FDI from Developing and Transition Economies: Implications for Development / United Nations. - Geneva and New York, 2006. - $332 \mathrm{p}$.

85. Vernon R. Competition policy toward multinational corporations

R. Vernon., 1974. - The American Economic Review, 64(2). - pp. 276-282.

86. Vernon R. International Investment and International Trade in Product Cycle // Quarterly Journal of Economics, Vol. 80 - № 2 / Vernon R., 1966. - pp. 190-207.

87. Vernon R. Multinational Enterprise and National Security / / Adelphy Papers, No. 74 / Vernon R. - London: The Institute of Strategic Studies, 1971. - pp. 17-36.

88. Vernon R. Sovereignty at bay: The multinational spread of U. S. Enterprises / R. Vernon. - New York: Basic Books, 1971. - 336 p.

89. Westney D. The multinational enterprise as an organization / The Oxford handbook of international business $1 /$ D. Westney, S. Zaheer., 2001. pp. 101-124.

90. What Kind of Shareholder Owns Most Nestlŭ SA (VTX: NESN) Stock? https: / / finance.yahoo.com / news / kind-shareholder-owns-most-nestl090905442.html.

91. Wilkins M. The emergence of multinational enterprise: American business abroad from the colonial era to 1914. / M. Wilkins. - Cambridge, Mass: Harvard University Press, 1970.

92. Wilkins M. The maturing of multinational enterprise: American business abroad from 1914 to 1970 \% M. Wilkins. - Cambridge, Mass: Harvard University Press, 1974.

93. WTO. Technological Innovation, Supply Chain Trade, and Workers in a Globalized World. WTO. - Geneva, 2019. https://www.wto.org/ english/res_e/booksp_e/gvc_dev_report_2019_e.pdf.

94. WTŌ. Trade and foreign direct investment / WTO. - Geneva, 1966. https: / /www.wto.org/english/news_e/pres96_e/pr057_e.html

95. Xiaoming $\mathrm{H}$. The renaissance of state-owned multinationals Thunderbird International Business Review, 58.2/ H. Xiaoming, L. Eden, M. Hitt., 2016. - pp. 117-129.

The article was received by the Editorial Board on July 14, 2019. 